nology. The new scheme is aimed at sixth formers only; the Schools Council, though greatly concerned with pupils in this age group, is also aiming at introducing engineering to younger pupils.

Commenting on this introduction of yet another way of introducing technology in schools, Mr G. B. Harrison, director of the Schools Council engineering project, said that it would be wrong at this stage to consider that any one method was better than the rest, and added that considerable research and evaluation of the different approaches were necessary.

\section{Defence Research}

The Select Committee on Science and Technology, investigating defence research in Britain, has heard from a number of witnesses how good is the work now being done. From the Electronic Engineering Association last week it got a different view-one which suggested that the establishments are good within their own military field but should not be encouraged to venture outside it. Success had come because the laboratories had immersed themselves in military problems, and thoroughly understood thembut they could not understand an industrial problem without becoming part of it. Did this mean that the staff of the establishments should be rapidly redeployed into industry ? The association thought notit would cause disruption on a large scale, and industry would be unable to take on large numbers of people. This painted a gloomy future for the establishments, gradually declining as the British defence budget declines.

When the association came to give evidence, it was represented by three witnesses: Commander $\mathrm{H}$. Pasley-Tyler, chairman of the EEA council, $\mathrm{Mr}$ W. D. H. Gregson from Ferranti, and Mr G. C. I. Gardiner from Hawker-Siddeley. Commander PasleyTyler argued that a new system was necessary for the successful execution of defence projects. Each project should have a manager with much more power, including power to control the project financially. Contracts should be given to industry from the start, with a firm operational requirement based on existing technology, a firm order and a fixed price. Only in this way could projects be finished in a reasonable time at a fair price. The one project which the witnesses could think of which had been tackled this way, the Nimrod aircraft project, had been a complete success. It had been finished two months early, within the original budget, and was "working beautifully".

Commander Pasley-Tyler tended to put the blame on the Ministry of Defence. "I have never come across a Defence Secretary who was capable of developing anything", he declared. The comptrollers in the ministry were excellent men, but they controlled nothing. Much greater powers should be vested in the project managers, and the Government should make much more intelligent use of its purchasing power. The witnesses saw a danger that the decline in defence spending would lead to a real decline in Britain's technological performance; something would have to be done to prevent this. The Government should either place large contracts with industry, or should allow it to make bigger profits. From an industrial delegation, this was perhaps predictable-but it carried conviction, and the Select Committee seemed impressed.

\section{Parliament in Britain}

\section{Electricity Generation}

THE new Minister of Power, Mr Ray Gunter, making his first announcement since he took over from $\mathrm{Mr}$ Richard Marsh, said that, in addition to savings of $£ 31$ million in the capital investment programme of the Central Electricity Generating Board announced on December 21, 1967, a further 116 million had now been saved "in the light of revised estimates in the trend of demand". (Oral answer, April 23.)

\section{Underground Cables}

Mr Reginald Freeson, Parliamentary Secretary at the Ministry of Power, gave details of the costs of laying cables underground. Costs per mile vary with voltage but, in the range of voltages from $11 \mathrm{kV}$ single circuit to $400 \mathrm{kV}$ double circuit, costs for overhead lines are $£ 1,100$ to $£ 5,000$ per mile. For underground lines the corresponding costs are $£ 5,000$ to $£ 930,000$ a mile. Every effort was made, Mr Freeson said, to pay attention to the amenity aspects of cables, and he suggested that the industry had a good record in this respect. Later Mr Freeson said that the gas industry had spent $£ 4 \cdot 2$ million in $1966-67$ on research and development, a figure which represented 0.8 per cent of turnover. The National Coal Board had spent $£ 3.7$ million in the same year, or $\mathbf{0 . 4}$ per cent of turnover. (Oral and written answers, April 23.)

\section{Oceanography}

MrS ShIrLex Williams, Minister of State at the Department of Education and Science, said that the Natural Environment Research Council had decided to move its Research Vessel Management Unit from Plymouth to Barry. Dr David Owen, Labour member for Plymouth Sutton, had expressed concern at the move. Plymouth Council, he said, had offered every facility to the NERC, and had not been told that the negotiations with the NERC were being discontinued. Mrs Williams said that the NERC had decided that Barry was the most suitable site for the unit; she was now considering the evidence on which it had based the decision. She added that the NERC had decided that there was no case for concentrating the research establishments dealing with marine science and oceanography, which were located in the areas best suited to the kind of work they were undertaking. She accepted this view. (Written answers, April 23.)

\section{Post Office}

Mr Joseph Slater, Assistant Postmaster General, gave a progress report on the National Data Processing Service. Nine existing computers had been taken over by the service; six in London and one each in Edinburgh, Derby and Portsmouth. They were two Elliott 405s, six English Electric Leo 326s, and one RCA Spectra 70/45. These "limited resources", he said, were already being used to undertake a certain amount of work for customers outside the Post Office; the RCA machine was on loan from English Electric pending delivery of an English Electric 4/70 machine. Four more $4 / 70$ s were in the Post Office plans, two in London and one each in Bristol and Leeds, and tenders had been invited from twenty-one manufacturers for two further computers for the London Heathrow Airport project. But he hinted that the supply of manpower rather than machines was likely to be the limiting factor. (Oral answers, April 25.) 